\title{
Serum lactate dehydrogenase in bronchial carcinoma
}

\author{
J . M . H I N T O N \\ From the Chest Clinic, Postgraduate Medical School, Hammersmith Hospital, London
}

Raised serum lactate dehydrogenase (LDH) levels in patients with various types of cancer have been reported on several occasions (Hill and Levi, 1954; Bierman, Hill, Emory, Reinhardt, and Samuels, 1955 ; Albaum, Antopol, Kabakow, Slapikoff, Blinick, Sussman, and Ginzburg, 1961). Gold (1961) reported raised levels in 28 out of 34 $(82 \%)$ proven cases of bronchial carcinoma. It was thought that if this finding was substantiated serum LDH would make a useful supplementary test in the diagnosis of bronchial cancer.

\section{METHOD AND CASE MATERIAL}

The method used was a colorimetric one (King and Wootton, 1964) developed from the method of Wróblewski and LaDue (1955).

The normal range in 45 controls (mean \pm 2 standard deviations) was 40 to 160 international units.

The controls were out-patients in whom there was no evidence of liver or heart disease, and the majority had e:ther chronic bronchitis or healed tuberculosis.

The diagnosis in the carcinoma cases was either histologically or cytologically proven (34) or was made on the basis of an undoubted clinical course (5). Table I shows the distribution of the histological types.

\section{RESULTS}

Only 10 out of the 39 patients had a serum LDH level of more than 160 i.u. at the first estimation. In a further six patients out of the 13 on whom two or more estimations were done, the level rose into the abnormal range as the disease progressed. Of these 16 patients with raised levels, 14 had clinical or biochemical evidence of secondary deposits at the time of the estimation, the biochemical evidence being a raised serum alkaline phosphatase. Of the 15 patients with abnormal levels who were followed for up to six months, all but one died $(93 \%), 11$ of them within three months. In contrast to this, 19 patients with normal values were followed for six months, and of these only six died $(38 \%)$. These results are expressed in Tables I and II.

The raised levels were mainly in the range 175300 i.u., but values from 500 to 2,100 i.u. were obtained in patients whose livers were markedly enlarged by metastases.

T A B LE I

DISTRIBUTION OF HISTOLOGICAL TYPES

\begin{tabular}{|c|c|c|c|c|}
\hline \multirow[b]{2}{*}{$\begin{array}{c}\text { Histological } \\
\text { Type }\end{array}$} & \multirow[b]{2}{*}{ Total } & \multicolumn{2}{|c|}{ Serum LDH Levels } & \multirow[b]{2}{*}{$\begin{array}{l}\text { Rise to } \\
\text { Over } \\
160 \text { i.u. }\end{array}$} \\
\hline & & $\begin{array}{c}\text { Normal } \\
\text { (under } \\
160 \text { i.u.) }\end{array}$ & $\begin{array}{c}\text { Abnormal } \\
\text { (over } \\
160 \text { i.u.) }\end{array}$ & \\
\hline $\begin{array}{l}\text { Squamous cell .. } \\
\text { Adenocarcinoma } \\
\text { Oat-cell .. } \\
\text { Undifferentiated } \\
\text { Not known .. }\end{array}$ & $\begin{array}{r}15 \\
4 \\
10 \\
5 \\
5\end{array}$ & $\begin{array}{r}14 \\
3 \\
6 \\
1 \\
5\end{array}$ & $\begin{array}{l}1 \\
1 \\
4 \\
4 \\
0\end{array}$ & $\begin{array}{l}2 \\
0 \\
2 \\
1 \\
1\end{array}$ \\
\hline Totals & 39 & 29 & 10 & 6 \\
\hline
\end{tabular}

TABLE II

SIX-MONTH SURVIVAL FIGURES

\begin{tabular}{c|c|c|c}
\hline $\begin{array}{c}\text { First Estimation } \\
\text { of Serum LDH }\end{array}$ & Total & Dead & Alive \\
\hline $\begin{array}{c}\text { Over 160 i.u. } \\
\text { Under 160 i.u. } \ldots\end{array}$ & 19 & 14 & 1 \\
\hline
\end{tabular}

\section{COMMENT}

In the literature there is a wide variation in the percentage of cases of carcinoma that have raised levels of serum LDH. Bierman et al. (1955), for example, found 121 out of $132(92 \%)$ in a series of many different types of histologically proven carcinoma cases, but, in contrast, Zimmerman and Weinstein (1956) found only 15 out of 30 . Albaum et al. (1961) found raised levels in the majority of 70 cases of stomach, large gut, and female genital tract cancer but mention that all their patients had metastases. In contrast, MacDonald, Simpson, and Nossal (1957) found normal levels in a small group of cases with localized neoplasia.

With bronchial carcinoma Gold (1961) found 28 out of 34 cases $(82 \%)$ with raised levels and Zimmerman and Weinstein (1956) found eight out of $13(62 \%)$. However, neither of these authors states whether metastases were present in his patients. In the present series, in which only 10 
out of $39(26 \%)$ had raised values at the first estimation, nine out of the 10 had definite evidence of metastases. Likewise, in four patients who had slowly growing, but nevertheless progressive, primary lesions but in whom there was no evidence of secondary deposits, the serum LDH value did not rise to an abnormal level in the course of six months.

A reasonable explanation of the discrepancy between the results in this series and those of Gold (1961) is that there was a much higher proportion of cases with metastases in his group of patients.

The results show that in practice the serum LDH is of little use in the diagnosis of bronchial carcinoma since in only a small proportion of cases is the level raised in the absence of secondary deposits. The main significance of a raised value is a prognostic one, since the majority of patients with abnormal levels had died within six months.
My thanks are due to Dr. R. Haslam, of the Biochemistry Department, for the estimations and to Dr. P. Stradling and Dr. G. W. Poole for permission to study their cases.

\section{REFERENCES}

Albaum, H., Antopol, W., Kabakow, B., Slapikoff, S., Blinick, G., Sussman, L., and Ginzburg, L. (1961). Serum enzyme alterations in cancer. Proc. Soc. exp. Biol. (N.Y.), 108, 569.

Bierman, H. R., Hill, B., Emory, E., Reinhardt, L., and Samuels, A (1955). Correlation of serum lactic dehydrogenase activity with the clinical status of patients with neoplastic diseases. Proc. Amer. Ass. Cancer Res., 2, 5.

Gold, J. A. (1961). Serum enzymes in bronchogenic carcinoma and other pulmonary diseases. Dis. Chest, 39, 62 .

Hill, B. R., and Levi, C. (1954). Elevation of a serum component in neoplastic disease. Cancer Res., 14, 513.

King. E. J., and Wootton, I. D. P. (1964). Micro-analysis in Medical Biochemistry. 4th ed., Churchill, London.

MacDonald, R. P., Simpson, J. R., and Nossal, E. (1957). Serum lactic dehydrogenase-A diagnostic aid in myocardial infarction J. Amer. med. Ass., 165, 35.

Wróblewski, F., and I aDue, J. S. (1955). Lactic dehydrogenase activity in blood. Proc. Soc. exp. Biol. (N.Y.), 90, 210.

Zimmerman, H. J., and Weinstein, H. G. (1956). Lactic dehydrogenase activity in human serum. J. Lab. clin. Med., 48, 607. 